\title{
JAPANESE BEETLE FEEDING AND SURVIVAL ON APPLE FRUITS
}

\section{ALIMENTAÇÃO E SOBREVIVÊNCIA DO BESOURO JAPONÊS EM MAÇÃS}

\author{
Evaldo Martins PIRES ${ }^{1}$; Robert Lee KOCH ${ }^{2}$ \\ 1. Universidade Federal de Mato Grosso, Campus Universitário de Sinop, Sinop, MT, Brazil. evaldo.pires@gmail.com; 2. University of \\ Minnesota, Department of Entomology, Saint Paul, MN, USA. koch0125@umn.edu
}

\begin{abstract}
Popillia japonica (Coleoptera: Scarabaeidae), Japanese beetle, is a polyphagous pest of many crops. In these crops, including apple, it acts primarily as a defoliator, causing economic damages. The objectives were to determine the ability of P. japonica to injury fruits of SweeTango variety apples and the suitability of apple fruits as a food source for this beetle. Popillia japonica was not able to injure the surface of intact fruits, which means that it is not a primary pest for apple fruits. The lifespan of the beetles when fed soybean leaves or apple with exposed endocarp was similar. Observations of the feces of the beetles suggest a potential physiological response due the change of food from soybean leaves to apple fruits. Therefore, we can conclude that the adults should not be considered as primary pests of apple fruits; however, they may act as secondary pests if the endocarp of the fruits is exposed by some other agent.
\end{abstract}

KEYWORDS: Food behavior. Injury. Minnesota. Popillia japonica. SweeTango.

\section{INTRODUCTION}

Popillia japonica Newman (Coleoptera: Scarabaeidae), Japanese beetle, is from Japan and has colonized much of the United States (SHANOVICH et al., 2019). This pest causes damage in agricultural and landscape settings by attacking plants, mainly reducing leaf surface area (POTTER; HELD 2002). This coleopteran arrived in the United States in 1911, through the importation of ornamental plants (Japanese iris), with the larvae in the planting substrate with roots (DICKERSON; WEISS 1918). During routine inspections, conducted in 1916, in plant nurseries near Riverton, New Jersey, United States, this insect was observed and reported (DICKERSON; WEISS, 1918; FLEMING, 1976). Currently, P. japonica has colonized almost all of the eastern United States and is moving into the Western Region with increasing reports in the Midwest Region of the country, where considerable population growth has been observed (POTTER; HELD, 2002; BAKER; POTTER, 2018). For example, in Minnesota, United States, $P$. japonica has been included on the list of the state's most concerning invasive pests that are priorities for research (CFANRS, 2016).

Popillia japonica is a significant insect pest due to its generalist feeding habits. A wide variety of host plants, exceeding 300 plant species, have been reported as viable food sources for adults (POTTER, HELD, 2002). Its voracity is another factor making this insect a major pest, because it can generate significant losses within a short period of time by skeletonizing leaves, injuring flowers (FLEMING, 1972; BAKER; POTTER, 2018), and even injuring fruits (DAVIS, 1920; FLEMING, 1972; HAMMONS et al., 2009). For example, $P$. japonica has been reported attacking fruits of grape, raspberry and apple (DAVIS, 1920; FLEMING, 1972; HAMMONS et al., 2009).

We observed the presence of P. japonica feeding on fruits of apple trees in apple orchards in Minnesota; however, the insects were not observed on intact apples (Prof. Evaldo M. Pires, personal observation). In Minnesota, commercial cultivation of this fruit has reached an average production of $10,569.47$ tons (23,30 million pounds) per year (USDA, 2018), that supplies both national and international markets. Due to the significance of this production, pests that attack and / or colonize this crop have driven efforts by producers and researchers in the area of plant protection to understand what pests occur in the state, and also, to implement management programs for apple tree pests (CIBOROWSKI, 2007; Minnesota Department of Agriculture, 2018). The ability of $P$. japonica to injure intact apple fruits was largely unknown. Apples injured or infected by diseases are preferred by $P$. japonica instead of intact fruits (HAWLEY; METZGER, 1940) and neglected orchards have shown the highest occurrences of this pest (SMITH; HADLEY, 1926). Previously in Minnesota, the invasive Harmonia axyridis (Coleoptera: Coccinellidae) was similarly found on injured apple fruits in orchards, but was later determined to be unable to cause primary injury to intact fruits (KOCH et al., 2004; GALVAN; KOCH; HUTCHISON, 2008).

Knowing the type of pest, the conditions in which the injuries occur and the acceptance of the 
substrate as a food source is important for integrated pest management (IPM) programs, since this knowledge assists in the elaboration of techniques and tactics of management (GALLO et al., 2002; PIRES et al., 2015). IPM programs classify pests as primary or secondary pests based on their ability to cause initial injury or not to plant tissues (GALLO et al., 2002; PIRES et al., 2015). Agents such as insects or birds acting as primary pests can facilitate access to those considered as secondary pests to fruits, because the primary pests cause initial lesions that allow the secondary pests to feed on and colonize this substrate (CHANG, 1968; BOUDREAU, 1972; TOBIN; DOLBEER; WORONECKI, 1989). Popillia japonica can act as a primary pest injuring some types of intact fruits, which facilitates aggregations of other pests (HAMMONS et al., 2009).

The objectives of this study were to determine: 1 . the ability of $P$. japonica to feed on apple fruits; and 2. the suitability of injured apple fruits as a late-season food source for P. japonica.

\section{MATERIAL AND METHODS}

Popillia japonica adults were randomly collected from infested soybean plants at the Agricultural Experiment Station (Lat. 44²59'19.9" N, Lon. 93 ${ }^{\circ} 10^{\prime} 59.1^{\prime \prime}$ W) on the Saint Paul Campus, University of Minnesota during apple crop season of 2018. Two experiments were performed to assess $P$. japonica feeding on apple fruits.

\section{Experiment 1}

The first experiment was carried out to assess the ability of these insects to feed on apple fruits under controlled conditions $\left(24 \pm 2{ }^{\circ} \mathrm{C}\right)$. In this experiment, intact or cut apple fruits of the SweeTango variety were offered to $P$. japonica adults to determine if they can feed on this food substrate. Plastic bags with a ziper (Ziploc brand), measuring $17.7 \times 19.6 \mathrm{~cm}$, were used. Ten lateral holes (five on each side) of 1 to $2 \mathrm{~mm}$ of diameter were made to allow gas exchange to occur. Five adult $P$. japonica were placed into each plastic bags containing intact apples or portions of cut apples (exposed endocarp) for 96 hours to verify if these insects were able to injure and feed on these substrates. A control treatment was performed using apples cut and kept under the same conditions, but without $P$. japonica, to compare with those that were exposed to the insects, so that the injuries caused by insects would not be confused with changes that occur naturally through the natural loss of water and wilting. Each treatment was performed in five replications. In addition, the feces of $P$. japonica was monitored to verify if it changed due to feeding on the apples. The insects were captured feeding on soybean plants, so changing the food substrate to apple may result in changes in feces (CHAPMAN, 2013).

\section{Experiment 2}

The second experiment was carried out to assess suitability of apple fruits as a late-season food source for $P$. japonica adults. In this study, fieldcollected adults (see above) were separated into couples (one male and one female) and kept in plastic pots (Great Value Snack Cup brand) with a $163 \mathrm{~mL}$ capacity. Four, 1- to 2-mm diameter holes were made in the lids to allow gas exchange to occur. The experiment was carried out with four treatments. In treatment 1 (T1) the beetles were fed soybean leaves. In treatment 2 (T2) no food was offered to beetles. In treatment 3 (T3) the beetles were fed a piece of apple (SweeTango variety) cut into a pyramidal shape (measuring $2 \mathrm{~cm}$ at the base and $2.5 \mathrm{~cm}$ high), leaving the skin at the base (Figure 1). In treatment 4 (T4) beetles were provided distilled water using a moistened cotton ball. These conditions were maintained until the death of all $P$. japonica. Ten replications were performed for each treatment. All pots were washed daily with neutral detergent to remove fecal matter and then dried with absorbent paper towels. The soybean leaves, the pieces of apples and the moistened cotton balls were also changed every 24 hours.

The data were submitted to the normality test of Anderson-Darling and the test of Scott-Knott, for multiple comparison of means. Statistical analysis were accomplished in ActionStat (EQUIPE ESTATCAMP, 2014) with $\mathrm{p}<0.05$ significance assuming error type I.

\section{RESULTS}

\section{Experiment 1}

In the first few minutes after assembling this experiment, all $P$. japonica stored with the cut apple, were observed on the surface of exposed endocarp. After 24 hours, the P. japonica kept in contact with the intact apple were observed distant from the fruit (Figure 1A) and, after examination of the surface of the apple, which occurred daily up to 96 hours (four days) no traces of injury were observed that could be characterized as a successful attack by $P$. japonica. On the other hand, the insects offered the cut apples were adhered to the exposed endocarp (Figure 1 B) presenting behavior that 
characterizes feeding due to movement of the mouth parts in contact with the surface of the endocarp.

Dry granular-shaped feces were observed on the interior surface of the plastic bag in the treatment with the intact apple offered to the insects. This can be explained because the excreta are still derived from the feeding on soybean leaves, where the insects were collected. On the surface of the cut apple, four granules of fecal material (Figure 1 B.1) and several brownish spots were observed, which characterizes liquid feces (Figure 1 B.2).
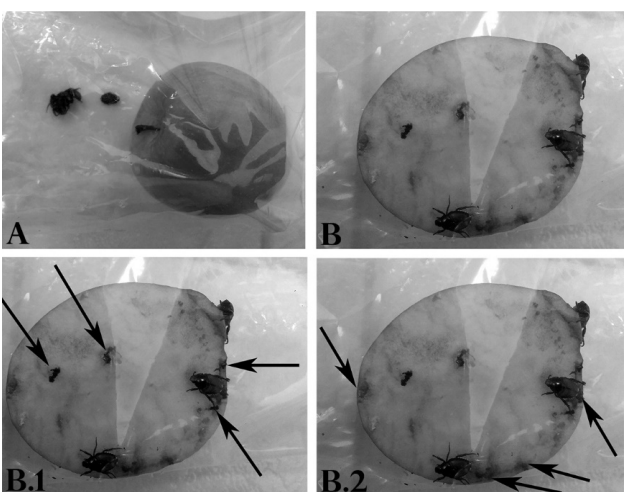

Figure 1. (A) Popillia japonica (Coleoptera: Scarabaeidae) adults far from of the intact apple. (B) Popillia japonica on the cut apple. (B.1) Dry feces on the exposed endocarp surface. (B.2) Dark regions that can to characterized as liquid feces on the exposed endocarp surface.

(Source: Image by Evaldo Martins Pires).

At 48 hours after the start of the evaluation, it was possible to observe and characterize the injuries caused by this insect on the surface of the endocarp of the cut apples. The kind of feeding injury observed can be characterized as depressions (irregularities) on the surface of the endocarp, which
At 24 hours after the start of the evaluation, some regions with depressions were observed on the surface of the cut apples. However, after this short period of exposure, it was not possible to distinguish depressions on the endocarp of apples with and without $P$. japonica. Therefore, at this period of time, any feeding injury caused by P. japonica could not be distinguished from the natural wilting process of the fruit due to dehydration.

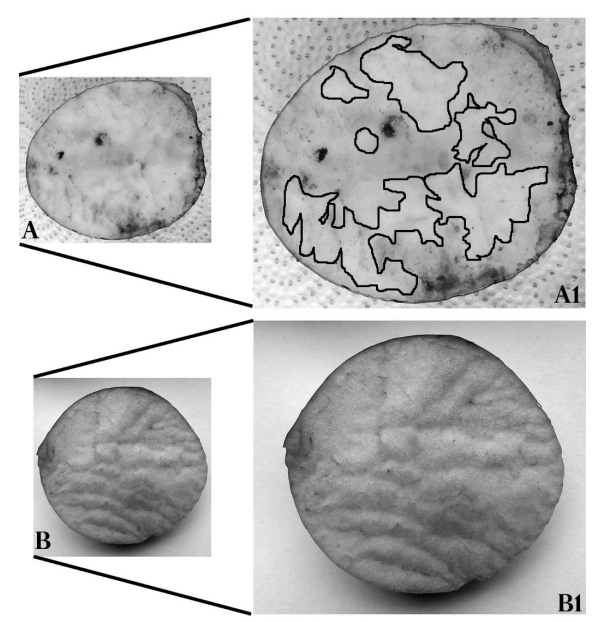

Figure 2. (A) Apple kept for 48 hours with adults of Popillia japonica (Coleoptera: Scarabaeidae). (A1) Endocarp with details of regions injured by $P$. japonica. (B) Apple kept for 48 hours without $P$. japonica. (B1) Endocarp showing of regions where wilting of the endocarp occurred without exposure to $P$. japonica.

(Source: Image by Evaldo Martins Pires). 
After 48 hours, no fecal matter was observed from $P$. japonica that were offered intact apples. On the other hand, the deposition of fecal matter by insects stored with cut apple began to present a pasty consistency, which was observed on the surfaces of the cut apples (Figure 3 A) and on the plastic pots (Figure $3 \mathrm{~B}$ and $\mathrm{C}$ ). The occurrence of fecal matter was not observed daily for insects that were fed with apple. On the other hand, six to 10 granules of dry fecal matter were counted per day, for those fed soybean leaves.

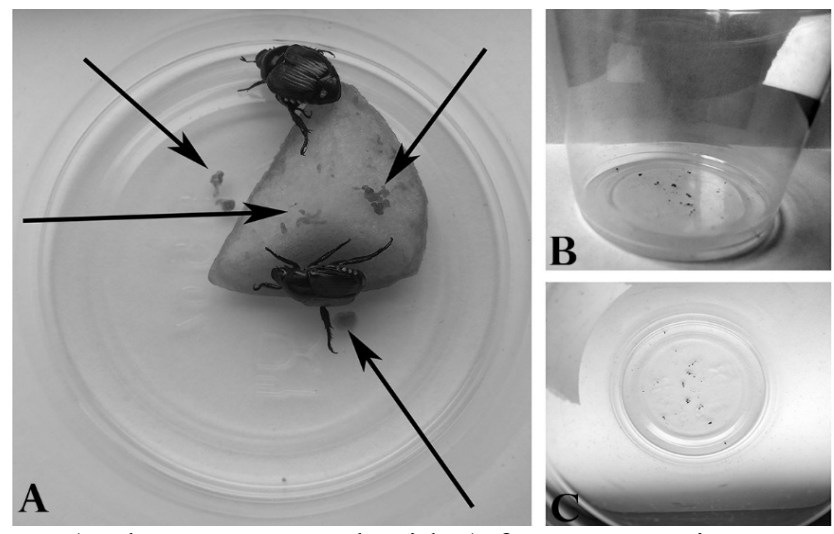

Figure 3. (A) Popillia japonica (Coleoptera: Scarabaeidae) feces presenting a pasty consistency on the surface of the cut apple and of the plastic pot used in this experiment. (B and C) Details of pasty fecal matter on the plastic pot surface.

(Source: Image by Evaldo Martins Pires).

\section{Experiment 2}

Lifespan of $P$. japonica was influenced by the rearing conditions $(\mathrm{F}=18.41, \mathrm{p}<0.05)$. Under the conditions in which $P$. japonica received edible food sources (soybean leaves or cut apple fruits) there was a greater lifespan than for insects that received only water or no type of food or water (Figure 4). Cut apple fruits were as suitable a food source for P. japonica as soybean leaves. This was evidenced by the similar lifespan of the beetles kept with soybean leaves (substrate from where they were removed in the field) or apples with exposed endocarp (Figure 4). Insect provided water had a greater lifespan than those with no food or water (Figure 4).

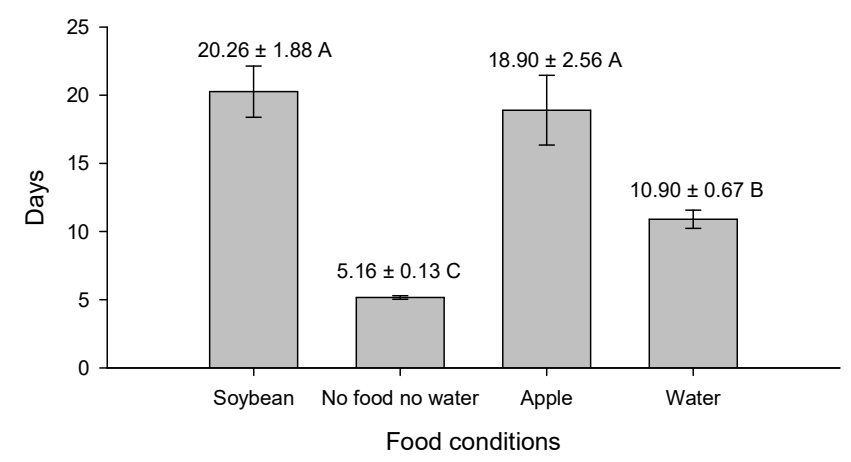

Figure 4. Lifespan of Popillia japonica (Coleoptera: Scarabaeidae) kept in different food conditions.

Means followed by the same letter do not differ by the Scott-knott test with $\mathrm{p}<0.05$.

\section{DISCUSSION}

The immediate search for apple by $P$. japonica after the assembly of the present experiments supports earlier statements that they are always in search of food or feeding (ALLSOPP, 1996). Due to the fact that $P$. japonica was unable to injure the intact apple fruits, this pest may be classified as a secondary pest for apple fruits.
Similar reports have been observed for other species of insects, such as $H$. axyridis ( $\mathrm{KOCH}$ et al., 2004; GALVAN; KOCH; HUTCHISON, 2008), that also were not able to break the skins of apples or grapes and that their feeding on these substrate is due to injuries caused by some other agents (e.g., wasps or birds) (CHANG, 1968; BOUDREAU, 1972; TOBIN; DOLBEER; WORONECKI, 1989). However, $P$. japonica was able to break intact grape 
fruits and, as a consequence, facilitate the aggregation of Cotinis nitida (Coleoptera: Scarabaeidae), which is a native species that is unable break the skins of this this fruit (HAMMONS et al., 2009).

The fact that $P$. japonica was unable to cause primary injury to intact apple fruits may suggest some hypotheses, which need to be tested. One such hypothesis is that the apple skin has sufficient resistance to $P$. japonica attack. Another hypothesis would be non-attractiveness of the intact apple. The absence of injury and suspended volatiles may make the intact apple unattractive to $P$. japonica attack, since the attractiveness of hosts to this insect has been shown to be driven by the interaction between the insect and plant-injury, which leads to chemical communication and can attract insects (METCALF; KOGAN, 1987; HAMMONS et al., 2009; BALDWIN, 2010), including the $P$. japonica in the larval (POTTER et al., 1992) and adult (LOUGHRIN; POTTER; HAMILTON-KEMP, 1995) stages. Research has reported that induced odors caused by feeding may assist in the search and selection of food sources with better quality for these beetles, and that injured plants present higher attractiveness to the insect than uninjured plants (LOUGHRIN; POTTER; HAMILTON-KEMP, 1995). For this reason, we might assume that $P$. japonica did not recognize the intact apple as a food source, since this insect is able to injure other fruits (DAVIS, 1920; HAMMONS et al., 2009).

After 24 hours, the endocarp of cut apples with and without $P$. japonica showed irregularities that may be due primarily to wilting (water loss by evaporation). By this time, the insects may be ingesting only the juices of the cut endocarp, which can be reinforced by the fact that the fecal matter observed during that period presented as traces or fecal stains, which characterizes feces in the liquid form and makes it difficult to diagnose if the insects were feeding or not on the apple mass. The behavior of ingesting water from fruits and vegetables is commonly observed in the mass rearing of some Coleoptera (PIRES et al., 2009; 2016).

After 48 hours of contact, the apples with exposed endocarp kept with $P$. japonica presented different deformations from those in which only the wilting of the endocarp surface occurred. Furthermore, the presence of feces with a paste consistency (i.e., no longer being liquid) can be considered an indicator that these insects were feeding on the apple mass and were adapting to the change of food source. Those exposed to apple likely ingested a higher quantity of carbohydrates, which can trigger mechanisms of differential secretion of digestive enzymes that can reduce the digestion of this nutrient and lead to the excess being excreted (CHAPMAN, 2013). The change of feces from liquid to pasty forms may be due to the insects initiating a process of greater control of water loss through regulating relative rates of production and reabsorption of urine (CHAPMAN, 2013).

There is much discussion about the lifespan of these insects due to the conditions under which they have been reared (DAVIS, 1920; SMITH; HADLEY, 1926; FLEMING, 1962; 1972). Thus, the results obtained in this study may contribute to an understanding of the feeding behavior of $P$. japonica on apple. The greater lifespan of those kept with cut apple fruit compared to water could refute the hypothesis that this insect ingests only the water of the apple, given that this behavior of ingesting water is observed in other Coleoptera such as the family Tenebrionidae (PIRES et al., 2009; 2016; BAEK et al., 2015). The lifespan of $P$. japonica feeding on soybean leaves and apple fruits in this study was similar to that found for individuals brought from the field and kept with sassafras leaves (SMITH; HADLEY, 1926). Based on the results of both the present experiments, the presence of injured, but not intact, apple fruits can allow the pest to survive for a period equivalent to other food sources. Furthermore, the extreme polyphagy of $P$. japonica was evidenced by it maintaining high rates of survival after switching from its food source of soybean in the field to apple fruit in the experiments.

Popillia japonica adults are listed among the insect pests that attack the leaves and fruits of apple (DAVIS, 1920). However, the results of this research show that $P$. japonica are not able to injure intact apple fruits of the SweeTango variety and that they only feed on fruits that have previous injuries. Thus, in orchards with few reports of organisms that make initial injuries to apple fruits, $P$. japonica may be considered a non-pest of the fruits themselves; however, the beetles do indeed attack the leaves. On the other hand, the similar longevity of $P$. japonica fed on injured apple fruits or soybeans leaves may result in $P$. japonica populations taking refuge and searching for food in apple orchards after senescence of the soybean crop or other host plants, which may necessitate monitoring of the orchards and paying more attention to the presence of primary pests. Future work should examine the susceptibility of additional varieties of apple fruits. 


\section{ACKNOWLEDGMENTS}

We thank the Universidade Federal de Mato Grosso for authorizing the first author to develop this research at the University of Minnesota; to the
Department of Entomology at University of Minnesota and also to those who have never lacked inspiration to present what nature has allowed us to elucidate.

RESUMO: Popillia japonica (Coleoptera: Scarabaeidae), besouro japonês, é uma praga polífaga de muitas culturas. Nessas culturas, incluindo maçãs, ela atua como um desfolhador, causando danos econômicos. Os objetivos foram determinar a capacidade de P. japonica produzir lesões em maçãs da variedade SweeTango e a adequação da maçã como fonte alimentar para esse besouro. Popillia japonica não foi capaz de lesionar a superfície das maçãs intactas, o que significa que ela não é uma praga primária para maçãs. O tempo de vida desse besouro alimentado com folhas de soja ou maçã com endocarpo exposto foi semelhante. Observações das fezes desse besouro sugere uma potencial resposta fisiológica devido a troca de alimento de folhas de soja para as maçãs. Desta forma, nós podemos concluir que os adultos não devem ser considerados como pragas primárias de maçãs; entretanto elas podem atuar como praga secundária se o endocarpo da fruta for exposto pela ação de outra agente.

PALAVRAS-CHAVE: Comportamento alimentar. Dano. Minnesota. Popillia japonica. SweeTango.

\section{REFERENCES}

ALLSOPP, P. G. Japanese beetle, Popillia japonica Newman (Coleoptera: Scarabaeidae): rate of movement and potential distribution of an immigrant species. The Coleopterists Bulletin, v. 50, n. 1, p. 81-95, 1996.

BAEK, S., PEREZ, A. E., TURCOTTE, R. M., WHITE, J.B., ADEDIPE, F., PARK, Y. Response of Tenebrio molitor (Coleoptera: Tenebrionidae) adults to potato: implications for monitoring and sampling. Journal of Stored Products Research, v. 60, p. 5-10, 2015. https://doi.org/10.1016/j.jspr.2014.11.002

BAKER, A. M., POTTER, D. A. Japanese beetles' feeding on milkweed flowers may compromise efforts to restore monarch butterfly habitat. Scientific Reports, v. 8, p. 12139, 2010. https://doi:10.1038/s41598-018$\underline{30731-z}$

BALDWIN, I. T. Plant volatiles. Current Biology, v. 20, n. 9, p. 392-397, 2010. https://doi:10.1016/j.cub.2010.02.052

BOUDREAU, G. W. Factors related to bird depredations. American Journal of Enology and Viticulture, v. 23, n. 2, p. 50-53, 1972.

CFANRS (College of Food Agriculture and Natural Resource Sciences) - University of Minnesota Minnesota's top 124 terrestrial invasive plants and pests: priorities for research. Saint Paul, Minnesota, 2016. 91 p.

CHANG, S. C. The wasps destructive to pears and apple fruits in Taiwan. Plant Protection Bulletin Taiwan, v. 10, p. 49-51, 1968.

CHAPMAN, R. F. The insects structure and function. 5. ed. Simpson, S. J.; Douglas. A. E. [eds.]. New York: Cambridge University Press, 2013. 929 p.

CIBOROWSKI, J. Integrated pest management manual for Minnesota apple orchards. 2. ed. Minnesota Department of Agriculture, Saint Paul, Minnesota. 2007, 64 p.

DAVIS, J. J. 1920. The green Japanese beetle. State of New Jersey, Department of Agriculture, Circular n. 30, Trenton, New Jersey, 2007, 33 p. 
DICKERSON, E. L., WEISS, H. B. Popillia japonica Newman, a recently introduced japanese pest. Canadian Entomologist, v. 50, n. 7, p. 217-221, 1918. https://doi.org/10.4039/Ent50217-7

EQUIPE ESTATCAMP. Software Action. Estatcamp - Consultoria em estatística e qualidade. São Carlos, São Paulo. 2014.

FLEMING, W. E. The Japanese beetle in the United States. Technical Bulletin 236, Washington, D.C.: USDA. 1962.

FLEMING, W. E. Biology of the Japanese beetle. Technical Bulletin 1449, Washington, D.C.: USDA. 1972.

FLEMING, W. E. 1976. Integrating control of the Japanese beetle - A historical review. Technical Bulletin 1545, Washington, D.C.: USDA. 1976.

GALLO, D.; NAKANO, O.; CARVALHO, R. P. L.; BAPTISTA, G. C.; BERTI-FILHO, E.; PARRA, J. R. P.; ZUCCHI, R. A.; ALVES, S. B.; VENDRAMIM, J. D.; MARCHINI, L. C.; LOPES, J. R. S. OMOTO, C. Manual de entomologia agrícola, 2. ed. Piracicaba: Fealq, 2002, 920 p.

GALVAN, T. L., KOCH, R. L., HUTCHISON, W. D. Impact of fruit feeding on overwintering survival of the multicolored asian lady beetle, and the ability of this insect and paper wasps to injure wine grape berries. Entomologia Experimentalis et Applicata, v. 128, n. 3, p. 429-436, 2008. https://doi: 10.1111/j.15707458.2008.00731.x

HAMMONS, D. L., KURTURAL, S. K., NEWMAN, M. C., POTTER, D.A. Invasive Japanese beetles facilitate aggregation and injury by a native scarab pest of ripening fruits. Proceedings of the National Academy of Sciences, v. 106, v. 10, p. 3686-3691, 2009. https://doi.org/10.1073/pnas.0811097106

HAWLEY, I. M., METZGER, H. L. 1940. Feeding habits of the adult Japanese beetle. Technical Bulletin 547, Washington, D.C.: USDA. 1940.

KOCH, R. L., BURKNESS, E. C., BURKNESS, S. J., HUTCHISON, W. D. Phytophagous preferences of the multicolored Asian lady beetle (Coleoptera: Coccinellidae) for autumn-ripening fruit. Journal of Economic Entomology, v. 97, v. 2, p. 539-544, 2004. https://doi:10.1603/0022-0493-97.2.539

LOUGHRIN, J. H., POTTER, D. A., HAMILTON-KEMP, T. R. Volatile compounds induced by herbivory act as aggregation kairomones for the Japanese beetle (Popillia japonica Newman). Journal of Chemical Ecology, v. 21, n. 10, p. 1457-1467, 1995. https://doi:10.1007/BF02035145

METCALF, R. L., KOGAN, M. Plant volatiles as insect attractants. Critical Reviews in Plant Sciences, v. 5, n. 3, p. 251-301, 1987. https://doi:10.1080/07352688709382242

Minnesota Department of Agriculture. Pest Index: An index of plant and insect pests of concern in Minnesota. http://www.Mda.State.Mn.Us/Node/1166 (Accessed: March 30, 2019). 2018.

PIRES, E. M.; PINTO, R.; SOARES, M. A.; SANTOS, G. P.; ZANUNCIO, T. V.; ZANUNCIO, J. C. Produção de percevejos predadores. 1. ed. Visconde do Rio Branco: Editora Suprema, 2009. 56 p.

PIRES, E. M.; SOARES, M. A.; OLIVEIRA, M. A.; FERNANDES, F. L. Introdução ao manejo integrado de pragas. 1. ed. Sinop: Editora MT Ciência, 2015. 70 p.

PIRES, E. M., SOARES, M. A., ZANUNCIO, J. C. Estrutura física, material e técnicas para criar percevejos predadores Asopinae. In: Pires, E. M. (Ed.), Controle biológico: estudos, aplicações e métodos de criação de predadores Asopíneos no Brasil. Viçosa: Editora UFV, 2016. p. 111-138. 
POTTER, D. A., PATTERSON, C. G., REDMOND, C. Influence of turfgrass species and tall fescue endophyte on feeding ecology of Japanese beetle and southern masked chafer grubs (Coleoptera: Scarabaeidae). Journal of Economic Entomology, v. 85, n. 3, p. 900-909, 1992. https://doi:10.1093/jee/85.3.900

POTTER, D. A., HELD, D. W. Biology and management of the Japanese beetle. Annual Review of Entomology, v. 47, p. 175-205, 2002. https://doi:10.1146/annurev.ento.47.091201.145153

SHANOVICH, H. N, DEAN, A. N, KOCH, R. L., HODGSON, E.W. 2019. Biology and Management of Japanese Beetle (Coleoptera: Scarabaeidae) in Corn and Soybean. Journal of Integrated Pest Management. v. 10, n. 1. https://doi.org/10.1093/jipm/pmz009

SMITH, L. B., HADLEY, C. H. The Japanese beetle. Technical Bulletin 363, Washington, D.C.: USDA. 1926.

TOBIN, M. E., DOLBEER, R. A., WORONECKI, P. P. Bird damage to apples in the Mid-Hudson Valley of New York. Hortscience, v. 24, p. 859, 1989.

USDA. National Agricultural Statistics Service - Quick Stats. 2018. Available in: https://www.nass.usda.gov/Quick_Stats/. Acessed on March 15th 2019. 